\title{
Book Review: Vulnerable Futures,
} Transformative Pasts: On Vulnerability, Temporality, and Ethics by Miri Rozmarin, Peter Lang, 2017, 194 pages. ISBN 978-1-78707-392-0 (ePub) (also available in print, ePDF and mobi)

\author{
Evelien Geerts \\ University of Birmingham, GB \\ e.m.I.geerts@bham.ac.uk
}

Keywords: Feminist philosophy; vulnerability; affirmation; neoliberalism; agency

Published in 2017 and originally planned in as a 2020 summer break read, feminist philosopher Miri Rozmarin's second book, Vulnerable Futures, Transformative Pasts: On Vulnerability, Temporality, and Ethics, turned into an even more timely, provocative reading experience than initially expected because of the global eruption of the now so familiar-feeling COVID-19 crisis. Well-written critical theoretical books that philosophically address concrete, situated phenomena of course always deeply affect their readers, but it is rare to find a book that succeeds at combining the highly theoretical with a clearly articulated feminist political praxis while developing a conceptual toolkit with which to analyze today's global pandemic-tainted Zeitgeist. And that, most importantly, does it all without falling back into what feminist science studies scholar Donna Haraway (2016) denounces as the highly binarized, problematic glorification of 'awful or edenic pasts and apocalyptic or salvific futures' (1) that appears to be haunting critical theory's past and present materializations.

Of interest to critical theorists, political philosophers, and feminist theorists with a penchant for difference-focused theorizing, Vulnerable Futures, Transformative Pasts argues for an even more affirmative outlook on the (inter)subjective phenomenon of vulnerability than the perspectives that have been offered in other recently-published feminist philosophical and critical theoretical works on the topic (see e.g., Mackenzie, Rogers \& Dodds 2014; Butler, Gambetti \& Sabsay 2016; Koivunen, Kyrölä \& Ryberg 2018). By presenting her readers with a relational political ontology aimed at tackling global-but always locally rooted and thus also vastly differing-crisis situations, inequalities, and injustices, Rozmarin skillfully avoids both doom-centered thinking and naïve optimism. By focusing on the importance of intervening in the here and now-or, to put it in Harawayan (2016) terms again, by enacting a 
well-grounded 'staying with the trouble'-when it comes to the examination of (often) structurally materialized vulnerabilities, the presented political ontology of vulnerability moreover pays attention to how a better, more just future could actualize itself. In a sense, this piece of critical theory was waiting to be (re)discovered during global pandemic times; times that, according to fellow feminist philosopher Judith Butler (2020), are weighing even more heavily on our spirit because of the many neoliberal capitalist cost-benefit approaches that are presently being employed around the world to allegedly 'help' us 'live' with the virus. Instead of truly safeguarding its most vulnerable citizens, however, these capitalist economy-protecting approaches and measures have only exacerbated a situation that had already massively increased pre-existing inequalities. Or as Butler (2020) so aptly puts it in a recent opinion piece that addresses said crisis from an American point of view:

'The virus alone does not discriminate, but we humans surely do [...]. It seems likely that we will come to see in the next year a painful scenario in which some human creatures assert their rights to live at the expense of others, re-inscribing the spurious distinction between grievable and ungrievable lives' (n. p.).

It is this troublesome distinction between those that have been made to matter and those that have not that also runs through Vulnerable Futures, Transformative Pasts as its ethicopolitical leitmotiv, and that in tandem with a neoliberalism-critical interpretation of vulnerability, to which we will now turn to.

The book's introductory pages immediately call for a more affirmative, less polarizing interpretation of the world and its inhabitants than the present-day neoliberal one-and the modern liberal interpretation that preceded it: Rozmarin (2017) starts by pointing at how vulnerability in today's neoliberal extractive capitalist world is often negatively pit against the idea of leading a 'full life' (2), meaning that people living under vulnerable conditions seen through such a neoliberal lens get signified as lesser subjects. Those that are unable to adhere to-or unwilling to conform to-the neoliberal discursive-ideological entanglements of hyperindividualism, hyperresponsibilization, hyperproductivity, and resilience (also see Halberstam 2011; Bracke 2016) because of their structurally marginalized positionalities, and are incapable of 'bouncing back' after adversity hits, regularly get labeled as unproductive, agency-less outsiders and outcasts. These subjects are nonetheless at the same time still hailed by the same neoliberal logic, branded as 'irresponsible' for not counter-acting and 'getting a grip'-which demonstrates neoliberalism's overattachment to all things agencyrelated. It is exactly this dichotomized 'vulnerability (no life) vs. agency (full life)' approach, plus the ironic outcomes of said approach (i.e., those that are allegedly rendered completely agency-less in the neoliberal narrative are responsibilized to counter-act within that narrative), that Rozmarin criticizes by connecting vulnerability to questions of power relations and (re)distribution of resources. And she does so while explicitly conceptualizing vulnerability as a 'transformative power' (2) or a 'driving force for transformative practices' (35) that does not rob subjects of their agential capacities. Per Rozmarin's point of view, a theory of transformative vulnerability boils down to a feminist political praxis, as it is invested in mapping out and correcting how certain infrastructures, conditions, and resources create different categories and lived experiences of vulnerability. In order to sketch an affirmative, holistic picture of vulnerability, said theory furthermore has to take the role of philosophical notions such as (inter)subjectivity, agency, and power, but also temporality, into account. Vulnerability is thus regarded as 'an axis around which to rethink the meaning of basic moral concepts such as justice, equality, autonomy, rights, and moral obligation' (2), including the perennial philosophical notions that the latter are connected to. 
The fact that Rozmarin emphasizes the affirmative in her analysis, however, does not mean that she is advocating for a naïve counter-theory in which vulnerable, marginalized subjects are to be exploitatively romanticized; Vulnerable Futures, Transformative Pasts actually frames vulnerability as an existential phenomenon that touches us all-albeit not equally, as Butler's just-explained commentary on the COVID-19 pandemic for instance also illustrates. For those that are interested in Rozmarin's philosophical neoliberalism-critical framing of vulnerability, Chapters 2 and 3, respectively titled 'Vulnerability, Ethics and Transformation' and 'Vulnerability and Becoming', are worth examining in detail. By drawing an intricate critical cartography of a plethora of contemporary thinkers philosophizing on the topic, Rozmarin here shows how especially the (neo)liberal definition of vulnerability (used by for instance political philosopher Robert Goodin and capabilities thinker Martha Nussbaum) lacks a detailed engagement with how the present-day subject is one that is always embedded inand embodied by-her/his milieu. And this relation to the subject's milieu and others should be considered when conceptualizing vulnerability. Or as Rozmarin (2017) writes:

'In none of the liberal accounts does people's active engagement with their reality and their endeavor to better their conditions and lives, use their vulnerability as a resource for social transformative existence. In fact, vulnerability is contradicted to the basic conditions for a person's agency, and thus associated with the lessening of personhood. What the liberal accounts do not question is whether this deep sociality, which is at the heart of vulnerability, should lead us to rethink our basic notions of subjectivity, freedom, and agency.' (45)

Next to this (neo)liberal, agency-denying approach, Rozmarin identifies what she calls a more post-liberal type of approach that makes room for vulnerability as 'the basis of agency rather than the negation to agency' (47) and the subject's relational entanglements with her/his environment. Such an approach does not instantaneously label vulnerability as the negative mirror image of agency (and vice versa), but, based upon Levinasian theory, regards the phenomenon as a 'sensitivity' (50) that is typical for human intersubjective relations.

This Levinasian view also fuels Butler's post-liberal approach. Butler's approach has mostly been spotlighted in Precarious Life ([2004] 2006)-her post-9/11 book that articulates an ethics of non-violence-and later works (see e.g. Butler 2009; 2016) in which the distinction between ontological precariousness and precarity, or the specific socio-economic and political conditions that have rendered certain subjects more vulnerable to injustice, poverty, and the like is made more intelligible. Reading Chapters 2 and 3, it instantaneously becomes clear that Rozmarin is in favor of Butler's vulnerability theory: Both thinkers plea for a revaluation of vulnerability as an ontological phenomenon and critical philosophical category, while additionally being equally critical of the (neo)liberal 'association of vulnerability with a weakness that calls for measures to reinstate autonomy and resilience' (Rozmarin 2017, 52). As is argued in this shared post-liberal approach, we are all bodily, needy, situated beings that rely on their infrastructural surroundings and milieu; therefore certain infrastructural conditions should be met for everyone to live what Butler calls a 'livable life' ([2004] 2006, xv).

Rozmarin's own theory of vulnerability is thus more post-liberal in nature, but that does not make it fully Butlerian, however: Lacking an engagement with the 'space/time' (Rozmarin $2017,61)$ in which subjects and their intersubjective relations are located in, Butler's theory according to Rozmarin remains rather abstract and is unable to theorize the transformative power of vulnerability that yet has to actualize itself. It is here where Vulnerable Futures, Transformative Pasts becomes extra captivating for the feminist philosophical reader, as it consequently intervenes in-and attempts to deconstruct-the rather oppositional 
'affirmation vs. vulnerability' debate (also see e.g. Braidotti 2006a). By drawing on her own expertise of feminist difference thinking and psychoanalysis-as represented by Luce Irigaray and Bracha L. Ettinger, amongst others-and Deleuzoguattarian feminist philosopher Rosi Braidotti's oeuvre, Rozmarin strikes the golden mean by reading Braidotti's take on various Deleuzoguattarian concepts, and Braidotti's affirmative ethics of becoming (2006a; 2006b) in particular, into Butler's vulnerability theory. This might seem contradictory at first, as Braidotti's affirmative ethics rests upon a critique of the recognitional identity dynamics that are at play in Levinasian-Butlerian philosophy, but Rozmarin pulls it off by delving deep into an persuasive analysis of the Deleuzoguattarian virtuality-actuality pair and the vulnerabilityas-affect idea that arises from it.

Chapters 2 and 3 basically form the theoretical backbone of Vulnerable Futures, Transformative Pasts, and although an engagement with the posthumanist, multispecies flourishing component of Braidotti's more recent work would have enlivened these particular sections even more-as vulnerability as an ontological condition most certainly isn't limited to human subjects-these chapters will surely provide its readers with enough critical-conceptual food for thought. The remaining chapters by the way complement the wellbalanced Butlerian-Braidottian theory of transformative vulnerability perfectly, as it is here where Rozmarin links vulnerability to an actual lived experience that a lot of beings on this planet share, namely, the encounter and connection with 'the maternal body as the first site of vulnerability' (Rozmarin 2017, 59). Reinvigorating Irigaray's antiphallogocentric philosophie féminine that critiqued the repression of the feminine, the maternal, and the material in Continental Western philosophy, Rozmarin draws on Irigaray's, but also other feminist thinkers', imaginary of femininity and erased mother-daughter relations to create an ethics of transformative, vulnerable encounters based upon the subject's primary encounter with the maternal body.

The above-sketched turn towards the maternal does not necessarily solve all of the ethicopolitical questions that arise when reading Vulnerable Futures, Transformative Pasts, thoughthink about what would happen, for instance, if, despite the acknowledgment of a maternal primary relationality, subjects were to actively refuse to recognize others' (and consequently also their own) vulnerable condition. This type of refusal has played out time and time again, and will, in these pandemic post-truth times, probably only gain in power ... Putting the question of refusal aside, the reader is left with the hopeful message that an alternative conceptualization of vulnerability within a toxic, extractive neoliberal societal framework is possible, and that such an exercise in rethinking vulnerability as an affect of our facing the future qua corporeal creatures, who encounter their dependency on a web of connections' (174) lies in resketching the relations between the levels of the ontological, the ethical and the political. It is that project of resketching, plus Rozmarin's own affirmative style of philosophizing, that turns Vulnerable Futures, Transformative Pasts into a timely and hope-filled critical theoretical work in what could be seen as pretty dark, crisis times.

\section{Competing Interests}

The author has no competing interests to declare.

\section{References}

Bracke, Sarah. 2016. "Bouncing Back: Vulnerability and Resistance in Times of Resilience." In: Vulnerability in Resistance, edited by Judith Butler, Zeynep Gambetti and Leticia Sabsay, 52-75. Durham-London: Duke University Press. DOI: https://doi. org/10.1215/9780822373490-004 
Braidotti, Rosi. 2006a. "Affirmation Versus Vulnerability: On Contemporary Ethical Debates." Symposium 10 (1): 235-54. DOI: https://doi.org/10.5840/symposium200610117

Braidotti, Rosi. 2006b. Transpositions: On Nomadic Ethics. Cambridge: Polity Press.

Butler, Judith. 2006. Precarious Life: The Powers of Mourning and Violence. London: Verso Books. Originally published in 2004.

Butler, Judith. 2009. Frames of War: When is Life Grievable? London: Verso.

Butler, Judith. 2016. "Rethinking Vulnerability and Resistance." In: Vulnerability in Resistance, edited by Judith Butler, Zeynep Gambetti and Leticia Sabsay, 12-27. Durham-London: Duke University Press. DOI: https://doi.org/10.1215/9780822373490

Butler, Judith. 2020. "Capitalism Has its Limits." Verso, March 30. Accessed September 1, 2020. https://www.versobooks.com/blogs/4603-capitalism-has-its-limits.

Butler, Judith, Zeynep Gambetti, and Leticia Sabsay (eds.). 2016. Vulnerability in Resistance. Durham-London: Duke University Press. DOI: https://doi.org/10.1215/9780822373490

Halberstam, Jack. 2011. The Queer Art of Failure. Durham-London: Duke University Press. DOI: https://doi.org/10.1215/9780822394358

Haraway, Donna J. 2016. Staying with the Trouble: Making Kin in the Chthulucene. DurhamLondon: Duke University Press. DOI: https://doi.org/10.1215/9780822373780

Koivunen, Anu, Katariina Kyrölä, and Ingrid Ryberg (eds.). 2018. The Power of Vulnerability: Mobilising Affect in Feminist, Queer and Anti-racist Media Cultures. Manchester: Manchester University Press.

Mackenzie, Catriona, Wendy Rogers, and Susan Dodds (eds.). 2014. Vulnerability: New Essays in Ethics and Feminist Philosophy. Oxford-New York: Oxford University Press. DOI: https:// doi.org/10.1093/acprof:oso/9780199316649.001.0001

How to cite this article: Geerts, Evelien. 2020. "Book Review: Vulnerable Futures, Transformative Pasts: On Vulnerability, Temporality, and Ethics by Miri Rozmarin, Peter Lang, 2017, 194 pages. ISBN 978-1-78707-392-0 (ePub) (also available in print, ePDF and mobi)." Redescriptions: Political Thought, Conceptual History and Feminist Theory 23(2), pp. 165-169. DOl: https://doi.org/10.33134/ rds.336

\section{Submitted: 09 September 2020 Accepted: 12 September 2020 Published: 15 December 2020}

Copyright: (c) 2020 The Author(s). This is an open-access article distributed under the terms of the Creative Commons Attribution 4.0 International License (CC-BY 4.0), which permits unrestricted use, distribution, and reproduction in any medium, provided the original author and source are credited. See http://creativecommons.org/licenses/by/4.0/.

\section{HUP HESINGI, Redescriptions: Political Thought, Conceptual History and published by Helsinki University Press.}

